\title{
Masterpiece Theatre for the emergency department
}

$\mathrm{H}$ is breathing was laboured, but his face, gnarled with great age, was regal in repose. She stood beside his stretcher acting as his advocate, telling everyone who he was, as if to save him the embarrassment of having to do it himself.

"He had several seasons as the leading winner, you know, Doctor," she said to me.

"Oh?" I said. I glanced at him and noticed limbs thin as dry twigs.

"Yes, he's a Hall of Famer, too. But the world long ago forgot him."

Now he is nearly 90 years old, with nothing but his memories. She is middle-aged, raising a couple of almostgrown kids on her own. He had her to thank, she knew that, even if he hadn't acknowledged her help. She had rescued him from his taste for liquor, the key that unlocked his normally reticent tongue. He would tell anyone who cared to buy him a drink about his life. Such was the vigor of his alcohol-fueled oratory that he never wanted for a wet whistle.

"I grew up with nothin' on a farm in Ontario," he would tell them. "Came a time when school was no longer of use to me; couldn't see a future in plowin' fields, either. All around me, people still looked to Mother England. They hadn't yet figured which way the future pointed, God save their king. Not me, though. Swore if I listened carefully to the breeze, I could hear the States calling out to me, whispering my name. I put away those fool schoolbooks and left home a lad whose head was filled with fancy ideas. I made my way south and crossed the border. I fell into the embrace of her stars and stripes as if into the arms of a tartedup woman. Need I say it? I was smitten. America, you see, had a dream she wanted to share with me."

Look, here's the thing: The kid was a natural athlete. And so he learned fast F and started winning when he was still a teenager. He grew emboldened, dare one say cocky, so he packed his kit and moved to New York. The Big Apple, see? His ability attracted a lot of attention among those in the know and he rose

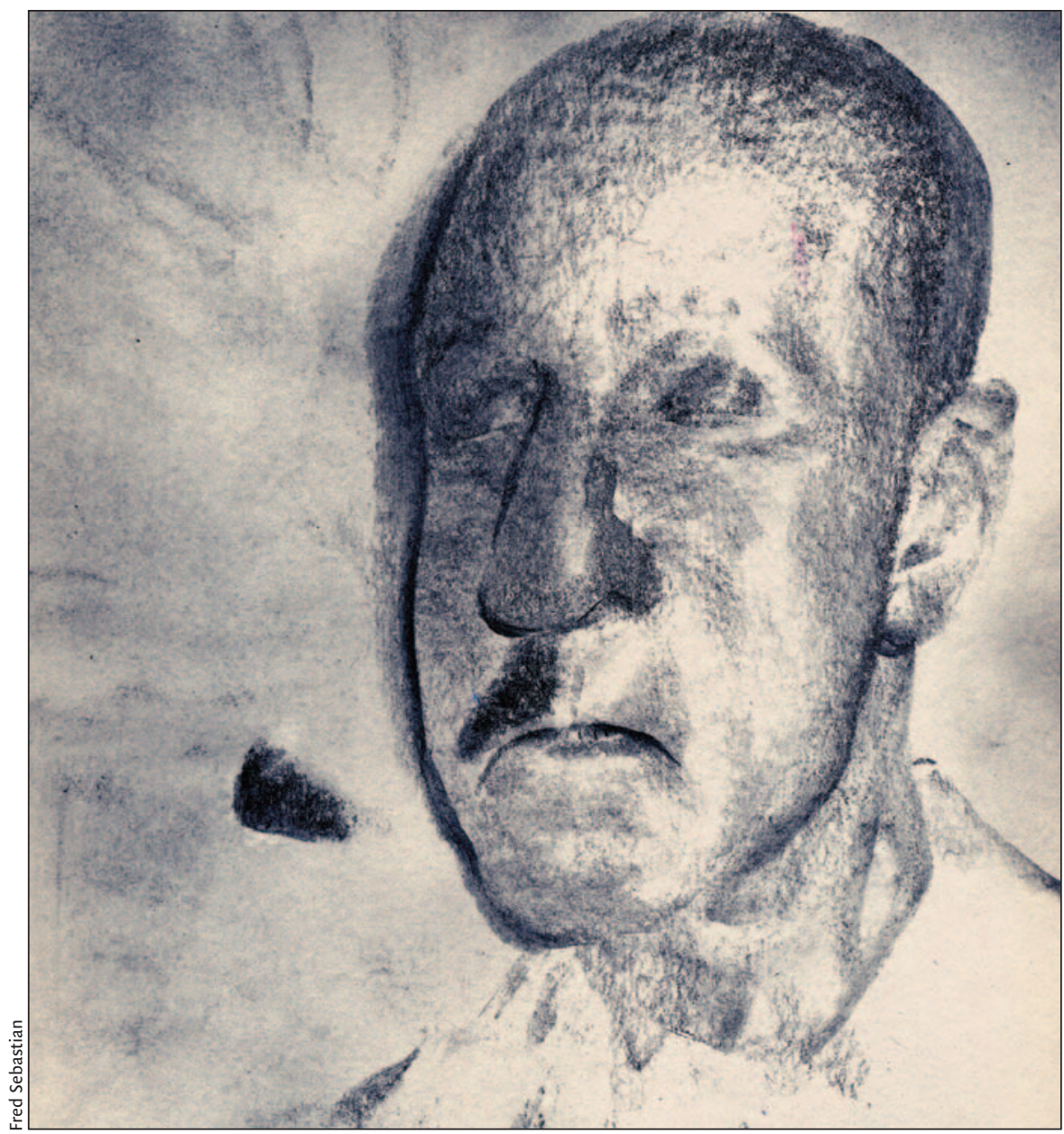

rapidly up the ranks. His reign as leader coincided with a time of great interest in the sport and he became well known: his picture in the papers, his name on the radio, people seeking his autograph and the like. He lived in the WaldorfAstoria for weeks on end, golfed with famous actors and received backstage passes to greet singers who wanted to meet him. Rags to riches, get it?

In the manner of all athletes, his career slipped away from him and he retired. Some say he stopped too soon, being still in his early thirties. But he knew it was time to quit. He kicked around a spell, but soon understood he was yesterday's news. America, that vulgar dame, had cast him out and tossed back the engagement ring. He limped north, home to Canada, carrying with him a bloated appetite with no means to feed it. He drifted from place to place and job to job, settling finally when his peripatetic ways were halted by the Pacific Ocean.

Decades later he was sober and in her kitchen. Sitting there with skin baked to leather and slim angular features, he seemed an anachronism, a throwback to an earlier era. Despite its colour and majesty, the event at which he excelled barely registered on the sports pages anymore. Replaced, instead, by men puffed up on steroids and too much money.

Filling his belly with strong, black coffee and home cooking, she slowly coaxed his stories from him. As he talked she felt transported from the dullness of her daily life; vicarious celebrity wrapped around her shoulders like a mink coat. She would close her eyes and an old black-and-white movie would roll. She could see him, a dandy in a silk 
shirt, mud splashed on his face. Then after, men with pencils and paper would gather around - journalists love a winner - their hats angled just so, cigarettes dangling from their envious lips, while the women, their hair pulled back, lips painted red, calves taut from impossibly high-heeled shoes, would sneak glances at him. He would smile and if insouciant that day, wink. The cameras would flash and flash.

I flashed the ophthalmoscope into his pupils, refocusing my concentration at his bedside. He was propped up on a gurney in the emergency department, a former athlete of note, someone of whom I was previously unaware. I stood over him in my white coat. He was breathing more comfortably as the oxygen whistled through nasal prongs. I moved my stethoscope to his frail chest. His lungs crackled and whined as his heart, galloping hard to the finish line, failed him, like his nerve and skill so many decades ago.

I tucked my stetho into my pocket and stepped back to observe him. He was indeed slight. But something else about his stature bothered me. And then in a rush of insight I understood everything.

His story had an engaging poetic arc, like a meteor shower against a cloudless night sky. I had felt an eagerness to bask in the twinkle of his distant star much as, I supposed, his female rescuer and intoxicated drink-buyers must have experienced. The narrative, though, was simply too good to be true.

It was his height, calling out like a nail to the head of a hammer, which made his celebrity implausible. Perhaps he was not a has-been, but a fib-making never-was.

He was or he wasn't. What did it matter? I had briefly ridden the crest of this story, indeed, filled in the blanks myself. No one made me glide along his biography like a surfer over the ocean's surging waves. And yet, the truth is, I enjoyed the ride: Masterpiece Theatre for the emergency department.

I shook off the day-dreamy thoughts. He was ill old man. I scribbled a few orders; I had my job to do.

\section{Brian Deady MD}

New Westminster, BC

\section{Book review}

\section{Chicken soup for the doctor's soul}

\author{
The Soul of the Physician: Doctors \\ Speaking about Passion, Resilience, \\ and Hope \\ Linda Gambee Henry, James Douglas Henry \\ AMA Press 2002 \\ 306 pp \$32.95 (for CMA members) \\ ISBN 1-57947-244-3
}

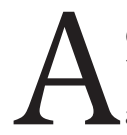
collection of 33 stories, as told by different physicians mediated by the authors, and divided into 3 sections (passion, resilience, hope), the purpose of The Soul of the Physician is to serve as a kind of static forum: doctors can access it and, perhaps, identify with what is written. How they will identify is bound to differ. Some may feel the reassurance that comes with knowing someone else has traveled this territory. Others may feel grateful that they've been spared some of the calamities shared in the book. And for others, these narratives may impart that rarest of all feelings: gratitude for being a physician.

This book rides the crest of narrative medicine (amply explored in the book's foreword), and even though the heavyweights are absent (e.g., Sherwin B. Nuland, Atul Gawande, Jerome E. Groopman, etc.), Soul is both an example of and a testament to this style of writing, due to its scope and the fact that it achieves a kind of folksiness: by folk, for folk, with a man-on-the-street kind of reportage. Sometimes, though, the sharing goes too far. The book advocates that doctors share their experiences with patients, which strikes me as relationship-warping; there should be a no-fly area for this sort of thing. Indeed, the authors write that "[s]haring stories creates a sense of partnership." But where does one stop? In the office, stories should begin and end with the patient. After all, patients see their doctor not to hear about their doctor's bugbears, but to sort out their own. Doctors who vent to their patients reverse the roles, and the patient, who ought to

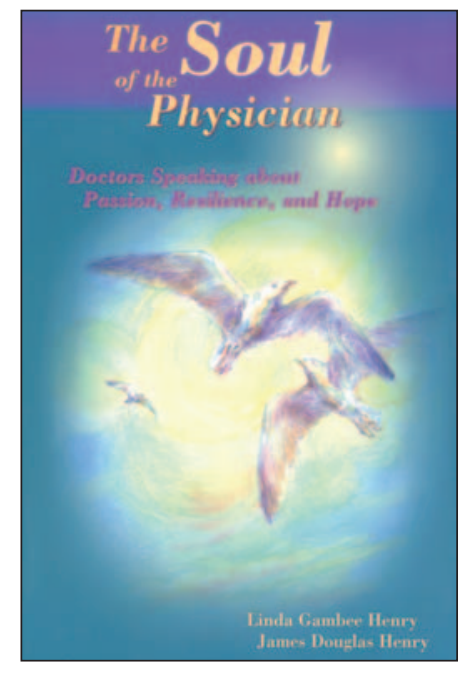

be chief object and subject, becomes secondary. We should not lean on our patients as therapists.

The chief metaphor of the book is the soul, and it would fair to call this book Chicken Soup for the Doctor's Soul. The soup is nourishing: the book revivified my taste for practising medicine. And it is the stories that provide the meat to the broth. The shtick around the idea of "soul" - in the introduction and larded as commentary throughout the book - is extraneous. These are tales of healing goodness meant to be good for you, nothing more.

The authors published a previous book on soul in health care and I gather they felt they could sing soul once again. If the soul could be divined, it would be through story. However, I wish it would be a story free of the soulless mush the Henrys subscribe to. The story's the thing; and the stories here do more than any silly, tacked-on, thesis-driven explanation can accomplish. What's the soul of a physician? What's a soul? What's a physician? This book will not tell you, but it will tell you a good story.

\section{Shane Neilson MD \\ Family physician \\ Guelph, Ont.}

